\title{
HUBUNGAN KESIAPAN ORANG TUA DENGAN KEMAMPUAN PSIKOMOTORIK SISWA DALAM PEMBELAJARAN DARING DIMASA PANDEMI COVID-19
}

\author{
${ }^{1}$ Eko Cahyono*, ${ }^{2}$ Eko Susetyarini, ${ }^{3}$ Endrik Nurrohman \\ ${ }^{123}$ Program Studi Pendidikan Biologi, Universitas Muhammadiyah Malang \\ e-mail:eko.cahyono703@gmail.com*
}

\begin{abstract}
COVID-19 is a type of virus that attacks the respiratory system, this virus is a family with SARS and MERS. The impact of this virus makes some countries force online learning, namely learning through internet social media, online learning has a very beneficial effect on the psychomotor aspects of students. The purpose of this study was to determine the relationship of parental readiness in online learning with students' psychomotor abilities. Subjects in this study were Mohammad Hatta elementary school students grade 3 and parents of students with 30 each. The parameters studied were online readiness including the provision of infrastructure tools, application systems, and online content. The parameters used for the psychomotor aspects of art and cultural materials and craft making a miniature house include the preparation stage, the process stage, the product. Data collection technique is observation using a Likert scale questionnaire. Data analysis using Pearson's task test. The results showed that the average readiness of parents during online learning in the provision of infrastructure tools was $73 \%$, application systems $62 \%$, online content $62 \%$. The average value of psychomotor ability is $81 \%$. The findings of this study are the correlation between parents 'readiness in online learning and students' psychomotor abilities $(0.638>0.361)$.
\end{abstract}

Keywords: covid-19; parental readiness; online learning; psychomotor

\begin{abstract}
ABSTRAK
COVID-19 merupakan sejenis virus yang menyerang sistem pernapasan, virus ini satu keluarga dengan SARS dan MERS. Dampak dari virus ini membuat sebagian Negara memberlakukan pembelajaran secara daring yaitu pembelajaran melalui media sosial internet, pembelajaran daring sangat memiliki manfaat terhadap aspek psikomotorik peserta didik. Tujuan penelitian ini untuk mengetahui hubungan kesiapan orang tua dalam pebelajaran daring dengan kemampuan psikomotorik siswa. Subyek dalam penelitian ini siswa SD Islam Mohammad Hatta kelas 3 dan orang tua siswa dengan jumalah masing-masing 30 orang. Parameter yang dikaji yaitu kesiapan dalam daring meliputi penyediaan alat infrastruktur, sistem aplikasi, dan konten daring. Parameter yang digunakan untuk aspek psikomotorik materi seni budaya dan prakarya pembuatan minatur rumah meliputi, tahap persiapan, tahap proses, produk. Teknik pengumpulan data secara observasi dengan menggunakan angket skala likert. Analisis data menggunakan uji korealasi pearson. Hasil penelitian menunjukan bahwa rata-rata kesiapan orang tua selama pembelajaran daring dalam penyediaan alat infrastruktur sebesar 73\%, sistem aplikasi 62\%, konten daring 62\%. Nilai rata-rata kemampuan psikomotorik sebesar $81 \%$. Temuan penelitian terdapat korelasi antara kesiapan orang tua dalam pembelajaran daring dengan kemampuan psikomotorik siswa $(0.638>0.361)$.
\end{abstract}

Kata kunci: covid-19; kesiapan orang tua; pembelajaran daring; psikomotorik

Cara mengutip: Cahyono, E., Susetyarini, E. \& Nurrohman, E. (2021). Hubungan Kesiapan Orang Tua dengan Kemampuan Psikomotorik Siswa dalam Pembelajaran Daring dimasa Pandemi Covid-19. Inteligensi: Jurnal Ilmu Pendidikan, 4(1), 19-26 


\section{PENDAHULUAN}

Covid-19 menjadi wabah penyakit yang sangat serius dan menjadi perhatian hampir di seluruh dunia (Susetyarini et al, 2019). Penularanya disebakan oleh kontak langsung dari manusia ke manusia yang tertular atau positif COVID-19 (Moss et al, 2020). Virus ini telah mewabah secara luas di banyak negara dan lebih dari 190 negara dan teritori lainnya (WHO, 2020). Kebijakan berbagai sektor telah ditetapkan oleh banyak negara yang terdampak (Wu, Leung, \& Leung, 2020). Indonesia salah satu negara yang terdampak COVID-19 melalui Menteri Pendidikan dan Kebudayaan membuat kebijakan pembelajar online atau dalam jaringan (daring) agar kegiatan pembelajaran dapat berlangsung dan aman.

Pembelajaran daring dalam jaringan (Online learning) pada dasarnya dapat menumbuhkan sifat kemandirian belajar peserta didik (Dewi, 2017). Menurut Sriwihajriyah (2012) pembelajaran daring adalah model pengajaran yang memanfaatkan fasilitas teknologi informasi dan komunikasi. Keuntungan dari pembelajaran online tidak terbatas sebuah ruang dan waktu, dapat memanfaatkan berbagi sumber yang sudah di sediakan internet, bahan ajar relatif mudah untuk bisa diperbaharui (Waryanto, 2006). Kesiapan orang tua terhadap perubahan metode pembelajaran menjadi faktor penting dalam ketuntasan belajar siswa. Kesiapan siswa dan orangtua merupakan salah satu faktor dari keberhasilan dalam menjalankan pembelajaran daring (Faslah, 2017).

$$
\text { Menurut Sabron }
$$
pembelajaran daring tidak hanya sebatas penggunaan internet melainkan melihat sisi lain yaitu lebih aman dan dapat memperluas informasi. Ada tiga hal yang harus diperhatikan dalam persiapan pembelajaran daring yaitu penyediaan alat infrastruktur, sistem aplikasi, dan konten e-learning (Winarno, 2013), ketiganya harus sejalan karena sebagai salah satu pembelajaran alternatif kegiatan proses pembelajaran dilaksanakan melalui pemanfaatan media komputer dan internet (Adawi, 2008). Hal tersebut untuk mendukung tercapainya pembelajaran termasuk ranah psikomotorik siswa.

Psikomotorik merupakan ranah yang berhubungan dengan aspek-aspek keterampilan yang melibatkan fungsi sistem saraf serta otot. Menurut Nurwati (2014) ranah psikomotorik mencakup persiapan, proses, dan produk, ketiganya tersebut harus berjalan dengan seimbang. Menurut Azmi (2017) aspek psikomotorik merupakan aspek yang meliputi sebuah keterampilan siswa atau proses pengetahuan yang banyak didasarkan dari pengembangan proses mental melalui beberapa aspek otot dan keterampilan. Ranah ini bisa dilihat melalui unjuk kerja siswa (Sugiarti, 2018), yang dilakukan berulang-ulang (Nurtanto, 2015), agar menumbuhkan rangsang positif terhadap pembelajaran bagi siswa (Rizqia, 2019).

Seni budaya dan prakarya merupakan salah satu pelajaran di tingkat sekolah dasar yang memberikan kesempatan peserta didik untuk bisa berkreasi. Seni budaya dan prakarya di berikan di jenjang pendidikan sekolah dasar agar tetap menumbuhkan rasa cinta siswa terhadap seni budaya indonesia. Rasa kecintaan akan menimbulkan minat dan kreativitas, dan apresiasi anak terhadap seni budaya indonesia (Mareza, 2017). Tujuan penelitian ini yaitu untuk 
mengetahui hubungan kesiapan orang tua dalam pebelajaran daring dengan aspek psikomotorik pada matapelajaran senibudaya dan prakarya.

\section{METODE PENELITIAN}

Penelitian ini menggunakan deskriptif kuantitatif. Lokasi penelitian dilaksanakan di SD Islam Mohammad Hatta, waktu penelitian adalah pada tanggal 25 Juni 2020. Subjek penelitian adalah siswa-siswi SD Islam Mohammad Hatta kelas 3 dan orang tua siswa dengan jumlah masing-masing responden siswa berjumlah 30 serta orang tua siswa berjumlah 30. Parameter kesiapan orang tua dalam pembelajaran daring menurut Winarno, (2013) yaitu kesiapan alat infrastruktur, sistem aplikasi, dan konten e-learning. Metode pengambilan data dengan cara observasi dan pengisian angket. Observasi (untuk (penggunaan teknologi informasi/ internet), angket skala linkert (untuk mengukur perilaku kesiapan orang tua dalam melakukan daring), disajikan pada tabel 1 berikut.

Tabel. 1 Kriteria Tingkat Kesiapan Oline (Daring)

\begin{tabular}{ll}
\hline \multicolumn{1}{c}{ Tingkat Kesiapan Online (Daring) } \\
\hline Level & Skor \\
Sangat Siap Online &.$>=80$ \\
Siap Online & $60=<X<80$ \\
Cukup Siap Online & $40=<\mathrm{X}<60$ \\
Tidak Siap Online & $X<40$ \\
\hline
\end{tabular}

Sumber : The Tiga Depok Online, 2020

Data kemampuan psikomotorik menggunakan parameter penilaian tahap persiapan, tahap proses, tahap produk. Metode pengumpulan data observasi dan penilaian menggunakan angket menurut Saputri (2018). Interpretasi skor persentase nilai kemampuan psikomotorik mengacu pada kriteria Ridwan (2005) yang disajikan pada tabel 2. Analisis data menggunakan uji korealasi pearson berikut.

\section{Tabel 2. Interpretasi Kriteria Nilai Psikomotorik Siswa}

\begin{tabular}{ll}
\hline Skor Rata- rata $(\%)$ & Kriteria \\
$0-20$ & Sangat tidak baik \\
$21-40$ & Tidak baik \\
$41-60$ & Cukup baik \\
$61-80$ & Baik \\
$81-100$ & Sangat baik \\
\hline
\end{tabular}

Sumber : Ridwan, 2005

\section{HASIL DAN PEMBAHASAN}

Hasil penelitian kesiapan orang tua dalam pembelajaran daring selama pandemi COVID-19 dengan kemampuan psikomotorik menunjukkan bahwa parameter kesiapan orang tua dalam pembelajaran daring hasilnya diperoleh bahwa kesiapan penyediaan alat infrastruktur $63 \%$ masuk dalam kategori sangat siap, 37\% siap, $0 \%$ cukup siap, dan $0 \%$ tidak siap. Kesiapan sistem aplikasi $25 \%$ masuk dalam kategori sangat siap, $60 \%$ siap, $15 \%$ cukup siap, dan $0 \%$ tidak siap. Konten e-learning 33\% sangat siap, $43 \%$ siap, $17 \%$ cukup siap, dan $7 \%$ tidak 
siap. Jika di rata-rata kesiapan orang tua dalam pembelajaran daring sebesar $66 \%$ menurut tabel The Tiga Depok Online, (2020) menunjukan level siap. Kesiapan orang tua tidak terlepas dari pemikiran betapa pentingnya pendidikan, dalam tahap kesiapan orang tua untuk melakukan pembelajaran daring tidak terlepas juga dari tingkat jumlah kasus COVID-19 yang terus meningkat hal tersebut yang membuat orang tua kuatir akan kesehatan anaknya yang disajikan pada gambar 1 berikut.

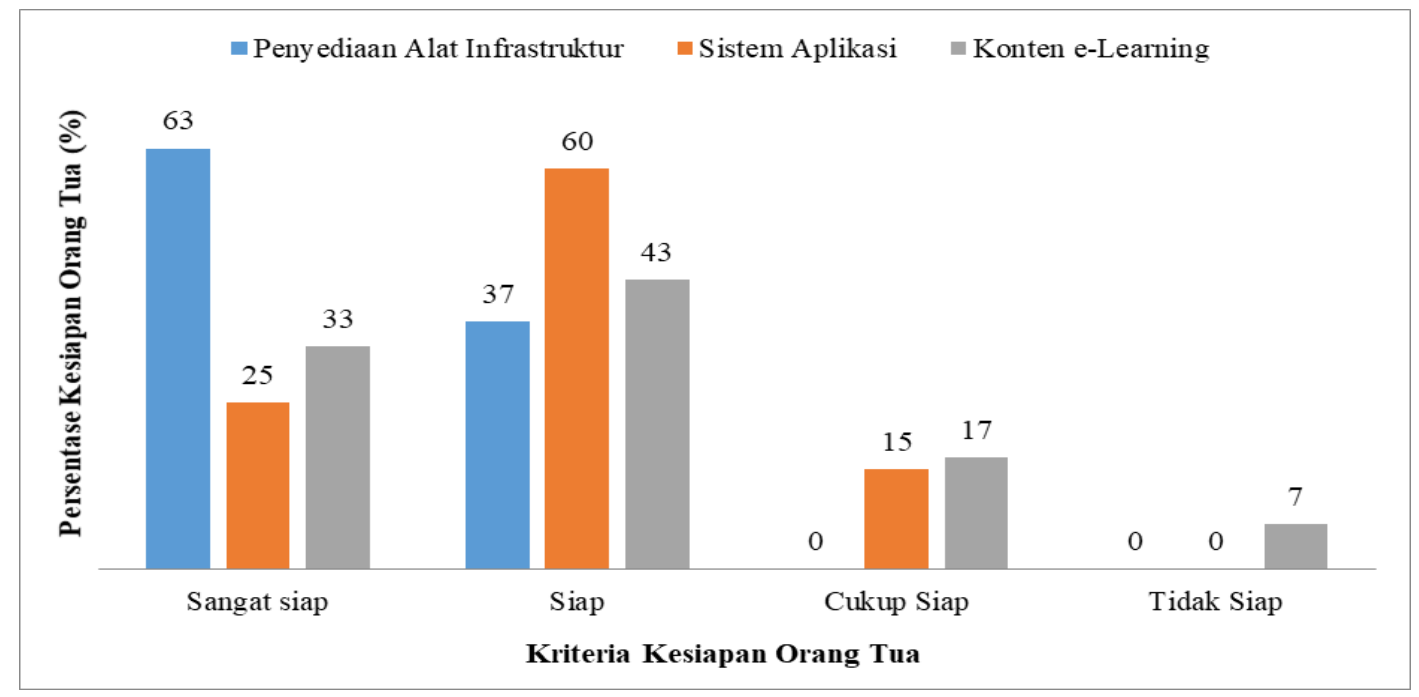

Gambar 1. Kesiapan Orang Tua Dalam Pembelajaran Daring

Kesiapaan orang tua dalam pembelajaran daring dalam jaringan (Online learning) menjadi salah satu faktor penentu terhadap proses pembelajaran siswa terutama pada ranah psikomotorik. Hasil rata-rata kemampuan psikomotorik siswa disajikan pada Gambar 2.

- Kemampuan Psikomotorik

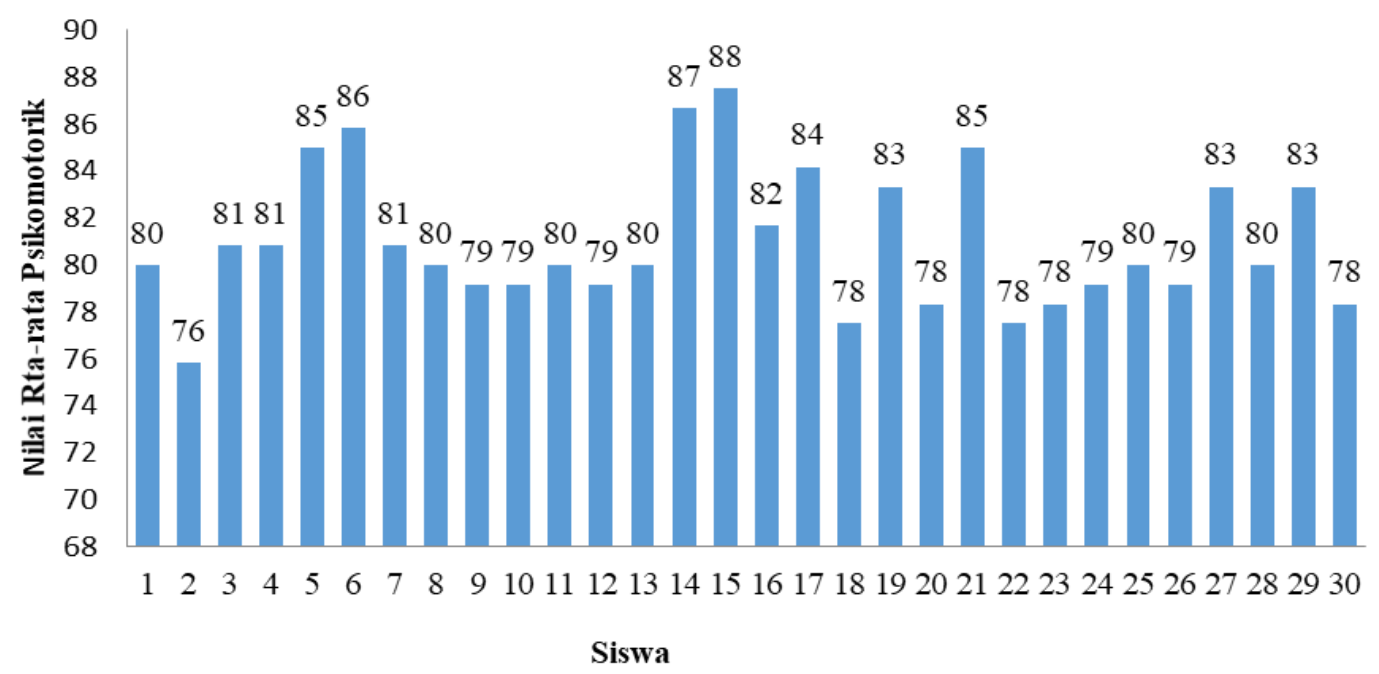

Gambar 2. Diagram Skor Rata-Rata Kemampuan Psikomotorik Siswa 
Rata-rata nilai kemampuan aspek psikomotorik berdasarkan Gambar 2, menunjukan $71 \%$ siswa sangat baik dalam menjalankan atau mengerjakan tugas pembuatan miniatur rumah, sedangkan sisanya sebanyak $29 \%$ siswa baik dalam mengerjakan tugas ini. Jika di rata-rata kemampuan psikomotorik sebesar $81 \%$ menurut Tabel. 2 interpretasi skor persentase Ridwan, (2005) menujukan kriteria sangat baik. Diagram pada Gambar 2 menunjukan bahwa nilai kemampuan psikomotorik siswa tidak terlepas dari kesiapan orang tua dalam pembelajaran daring. Hasil tersebut dibuktikan dengan uji korelasi pearson yang disajikan pada gambar 3 berikut.

Tabel 3. Hasil Analisis Korelasi Pearson

\begin{tabular}{lllll}
\hline Parameter & $F_{\text {hitung }}$ & $F_{\text {tabel }}$ & Sig & Kesimpulan \\
\hline Kesiapan orang tua (daring) & 0.638 & 0.361 & 0.000 & Ada korelasi kedua \\
Kemapuan psikomotorik & 0.638 & 0.361 & 0.000 & variabel \\
\hline
\end{tabular}

Berdasarkan tabel 3 nilai signifikansi antara kesiapan orang tua (daring) dengan kemampuan psikomotorik adalah sebesar $0.000<0.05$ yang berarti menunjukan adanya korelasi yang signifikansi antara variabel kesiapan orang tua (daring) dengan variabel kemampuan psikomotorik. Berdasarkan $F_{\text {hitung }}$ untuk hubungan kesiapan orang tua (daring) dengan kemampuan psikomotorik adalah sebesar $0.638>0.361$ maka dapat disimpulkan kedua variabel kesiapan orang tua (daring) dengan kemampuan psikomotorik memiliki hubungan, dengan derajat hubungan korelasi kuat, bentuk hubungan positif yaitu kesiapan orang tua (daring) dengan kemapuan psikomotorik memiliki nilai 0.638 , tidak bertanda negatif berarti hubungan keduanya hubungan positif. Jadi bisa disimpulkan bahwa semakin tinggi kesiapan orang tua dalam pembelajaran daring semakin tinggi nilai rata-rata kemampuan psikomotorik siswa. Kesiapan daring merupakan kegiatan kesanggupan seseorang untuk berinteraksi melalui media internet. Kesiapan daring dapat dilakukan oleh siapa dan kapan saja, salah satunya kesiapan orang tua dalam menyiapkan pembelajaran daring untuk anaknya selama pandemi Covid-19. Menurut Sardiman, (2007) kesiapan daring sangat dibutuhkan dalam proses belajar, karena semua aspek yang ada di dalam siswa penting untuk diperhatikan dalam menjaga dan meningkatkan kualitas pembelajaran yang berlangsung. Kesiapan daring dapat meningkatkan kemampuan aspek psikomotorik siswa terbukti dari beberapa penelitian. Menurut Purwaningsih, (2017) pembelajaran melalui e-learning dapat meningkatkan aspek psikomotorik siswa dan penelitian yang dilakukan oleh Hastomo, (2013) pada pembelajaran PAI bahwa pembelajarab elearning bermanfaat sebagai media pendukung dalam proses pembelajaran PAI, karena dengan media e-learning siswa dapat mempelajari materi PAI secara lebih intensif dan mandiri.

Penyediaan alat infrastruktur adalah salah satu yang harus ada dalam proses pembelajaran daring. Menurut Winarno, (2013) penyediaan alat infrastruktur dapat berupa personal computer (PC), jaringan komputer, internet dan perlengkapan multimedia, serta peralatan teleconference (apabila diperlukan fasilitas teleconference). Semakin majunya 
teknologi alat-alat komunikasi untuk pembelajaran daring sangat mudah diperoleh atau di beli dengan harga relatif terjangkau tergantung tahun pengeluaran alat elektronik. Menurut Hendrastomo, (2008) infrstruktur dapat berupa aset fisik yang dirancang kedalam sebuah sistem, sehingga yang akan memberikan pelayanan publik yang sangat penting. Infrastruktur memberikan layanan dan dukungan yang kedepannya akan dimanfaatkan kelangsungan sebuah system termasuk sistem pembelajaran.Konten $e$ learning (daring) adalah tema pembelajaran yang disampaikan siswa untuk dapat diakses dan dipelajari kapan atau dimanapun berada, konten daring harus menarik sehingga peserta didik dapat semangat untuk mempelajarinya. Menurut Winarno, (2013) selain konten dapat berupa bahan ajar berbentuk multimedia interaktif, yang dapat disimpan dalam LMS sehingga siswa dapat mengakses konten tersebut kapan dan dimana saja. Menurut Hendrastomo, (2008) konten belajar e-learning (daring) dapat dikatakan enrichment, apabila siswa dengan cepat menguasai materi yang diberikan oleh guru. Siswa akan memmpunyai kesempatan untuk mengakses materi daring yang sudah dikembangkan khusus sesuai kemampuan mereka dengan tujuannya yaitu untuk memantapkan penguasaan materi yang telah guru berikan.

Menurut Slameto, (2013) kesiapan daring dalam mendukung proses pembelajaran dipengaruhi oleh 3 aspek yaitu kondisi fisik sangat berhubungan dengan tingkat kesehatan individu. Kondisi mental memiliki kaitannya dengan kecerdasan setiap individu, kecerdasan pada tingkat yang lebih tinggi memiliki tingkat kesiapan yang lebih tinggi pula untuk menghadapi suatu tantangan. Tingkat emosional memiliki kaitan dengan motif kegiatan yang dilakukan individu. Aspek keterampilan, pengetahuan, dan pengertian yang telah dipelajari menjadi salah satu aspek, karena semakin banyak keterampilan dan tinggi pengetahuan yang dimiliki individu akan memiliki nilai dengan tingkat kesiapan yang lebih tinggi. Kesiapan daring yang dilakukan orang tua demi kelancaran proses pembelajaran untuk anaknya tidak terlepas dari tingkat kekuatiran akan wabah Covid-19 dimasa pandemi. Tingkat kekuatiran dipicu dengan jumlah kasus penderita Covid-19 yang terus bertambah di Indonesia. Menurut The Tiga Depok Online (2020) berdasarkan hasil rekapitulasi pembelajaran daring selama pandemi Covid-19 yang dilakukan SMP Negeri 3 Depok hasilnya $75,22 \%$ responden khawatir anaknya dapat terjangkit covid19 jika tetap dilakukan proses pembelajaran tatap muka dan $82,97 \%$ responden sangat siap mendampingi pembelajaran daring. Menurut data hasil survei Radio Republik Indonesia dengan lembaga survei Indo Barometer membuktikan tingginya prosentase tingkat kekhawatiran masyarakat terhadap Covid19, yakni mencapai $68 \%$. Sedangkan respons tidak terlalu khawatir sebesar 30,2 $\%$ dan tidak khawatir sama sekali sebesar 1,8 \%, artinya, akumulasi persentase masyarakat yang tidak khawatir sebesar 32 $\%$. Masyarakat umum yang tidak kuatir berarti sudah mengetahui cara mencegah COVID-19 dan sudah siap segala resiko yang akan terjadi, salah satunya belajar menggunakan metode daring atau online. 


\section{SIMPULAN}

Kesimpulan penelitian ini berdasarkan uji korelasi pearson kesiapan orang tua dalam pembelajaran daring memiliki korelasi dengan kemapuan psikomotorik, dengan bentuk hubungan positif yang artinya semakin tinggi tingkat kesiapan orang tua dalam pembelajaran daring semakin tinggi nilai kemampuan psikomotorik siswa.

\section{DAFTAR PUSTAKA}

Adawi, R. (2008). Pembelajaran Berbasis Learning. Universitas Negeri Medan. BAHAS.

DOI: https://doi.org/10.24114/bhs.v0 i69TH\%20XXXV.2397

Azmi, F, Halimah, S, Pohan, N. (2017). Pelaksanaan Pembimbingan Belajar Aspek Kognitif, Afektif Dan Psikomotorik Siswa Di Madrasah Ibtidaiyah Swasta Amal Shaleh Medan. Jurnal Kajian Ilmu Pendidikan Islam dan Humaniora. 1 (1): $15-28$

Dewi, L. (2017). Designing Online Learning In Higher Education Institution: Case Study In Curriculum And Instruction Course At Indonesia University Of Education. Edutech. 16 (2): 205 221

Faslah, R \& Santoso, B.H. (2017). Analisis Kesiapan Implementasi E-Learning Menggunakan E-Learning Readiness Model. POSTIF. 3 (2): 113 - 120

Hastomo, H.S. 2013. Efektivitas Media Pembelajaran E-Learning Terhadap Prestasi Belajar Pendidikan Agama Islam Siswa Di Sma Negeri 1 Yogyakarta. Skripsi. Universitas Islam Negeri Sunan Kalijaga: Skripsi.Yogyakarta

Hendrastomo, G. (2008). The Dilemma and the Challenge of E-learning. $D i$ muat dalam majalah ilmiah pembelajaran, 4 (1): 1-13
Kompas.com, (2020). Survei RRI-Indo Barometer: Tingginya Kekhawatiran Warga atas Wabah Covid-19. https://nasional.kompas.com/read/20 20/03/20/13185191/survei-rri-indobarometer-tingginya-kekhawatiranwarga-atas-wabah-covid-19 (diakses 28 April 2020)

Mareza, L. (2017). Pendidikan Seni Budaya Dan Prakarya (Sbdp) Sebagai Strategi Intervensi Umum Bagi Anak Berkebutuhan Khusus. Universitas Muhammadiyah Purwokerto: Jawa Tengah.

Moss, P., Barlow, G., Easom, N., Lillie, P., \& Samson, A. (2020). Lessons for managing high10 consequence infections from first COVID-19 cases in the UK [Correspondence]. The Lancet, 395(10227), e46. https://doi.org/10.1016/ S01406736(20)30463-3

Nurtanto, M, Sofyan, H. (2015). Implementasi Problem-Based Learning Untuk Meningkatkan Hasil Belajar Kognitif, Psikomotor, Dan Afektif Siswa Di SMK. Jurnal Pendidikan Vokasi. 5 (3): 352 - 364.

Nurwati, A. (2014). Penilaian Ranah Psikomotorik Siswa Dalam Pelajaran Bahasa. Edukasia. 9 (2): 385-400.

Purwaningsih, R, dkk. (2017). Pengaruh Penggunaan E-Learing Dengan Schoology Terhadap Hasil Belajar Peserta Didik. Jurnal Pembelajaran Fisika (JPF). 5 (4): 51 - 61

Radarbali, Jawapos. (2020). Kreativitas, Kunci Sukses Pembelajaran Daring saat Pandemic Covid-19. https://radarbali.jawapos.com/read/2 020/04/13/188590/kreativitas-kuncisukses-pembelajaran-daring-saatpandemic-covid-19. (diakses $04 \mathrm{Mei}$ 2020)

Ridwan. (2005). Skala Pengukuran Variabel-Variabel Penelitian. Bandung : Alfabeta

Rizqia, M, dkk. (2019). Analisis Psikomotorik Halus Siswa Ditinjau 
Dari Keterampilan Menggambar Anak Usia Dasar SD. Journal of Islamic Primary Education, 2 (2): 45-53.

Sabron, dkk. (2019). Pengaruh Daring Learning Terhadap Hasil Belajar IPA Siswa Sekolah Dasar. PROSIDING. 1(1): 1-5.

Sardiman. (2007). Interaksi dan Motivasi Belajar Mengajar. Jakarta: Rajagrafindo Persada.

Slameto. (2013). Belajar dan FaktorFaktor yang Mempengaruhinya. Jakarta: Rineka Cipta

Sriwihajriyah, N, Ruskan, E.L, \& Ibrahim, A. (2012). Sistem Pembelajaran dengan E-Learning untuk Persiapan Ujian Nasional pada SMA Pusri Palembang. Jurnal Sistem Informasi . 4 (1): $450-467$.
Sugiarti. (2018). Penilaian Psikomotor Siswa Pada Pembelajaran Fisika Melalui Model Pembelajaran Guided Inquiry. PASCAL. 2 (1): $79-84$.

Susetyarini, E., Latifa, R., Wahyono, P, \& Nurrohman.

E. (2019). Phytochemical Screening Of Gotu Kola Extract (Centella asiatica (L.) Urban.) Preliminary Research to Find Active Compounds Potential for Immunomodulator Candidate. ICOSITER-2019. Intitut Teknologi Sumatera.

The Tiga Depok Online, 2020. Rekapitulasi Data Angket Pemb.Online Cegah Covid-19 Dan Rekomendasi Sekolah. https://degadeonline.com/2020/03/17 /rekapitulasi-data-angket-pembonline-cegah-covid-19/ (diakses 28 April 2020) 